\title{
Sosialisasi Tanggap Bencana Covid-19 Di Desa Batu Balian Kecamatan Simpang Empat Kabupaten Banjar Provinsi Kalimantan Selatan
}

\author{
Apriansyah $_{5}{ }^{1 *}$, Lalita Hanief ${ }^{2}$, Andhika Wiguna Briantama ${ }^{3}$, Dewi Utari ${ }^{4}$, Dimas \\ Fernandayarin $^{5}$, Elisa Yulianti ${ }^{6}$, Hilda Elia Ningsih ${ }^{7}$, Muhammad Fariz , Sukma Endah \\ Darmayanti ${ }^{9}$ \\ ${ }^{1,2}$ Universitas Lambung Mangkurat, Fakultas Ilmu Sosial dan Ilmu Politik, \\ Jl. H. Hassan Basry, Banjarmasin, Indonesia, \\ ${ }_{3,4,5,6,7,8,9}$ Mahasiswa Program Studi Ilmu Pemerintahan, Universitas Lambung Mangkurat, \\ Fakultas Ilmu Sosial dan Ilmu Politik, \\ Jl. H. Hassan Basry, Banjarmasin, Indonesia, \\ *Email Korespondensi: apriansyah.fisip@unlam.ac.id
}

Diajukan

29 Oktober 2021

\section{Informasi Artikel}

Diterima

20 November 2021
Diterbitkan

30 November 2021

\section{Keywords:}

Sosialisasi

Tanggap Bencana

Desa Batu Balian

Pengabdian Masyarakat

\begin{abstract}
The community in Batu Balian Village has various characteristics. There are several RTs whose people do not have more awareness to comply with existing health protocols, people also tend not to believe in the existence of the Covid19 Virus. So we need a particular action/method used to solve the problem. Therefore, it is necessary to carry out Socialization activities to Build a Covid19 Disaster Response Village in Batu Balian Village. This research uses the socialization method. The socialization was carried out to students of the Government Science Study Program, FISIP University of Lambung Mangkurat. This socialization was carried out to educate the Batu Balian village community about the dangers of, preventing, and overcoming the Covid-19 disaster, amid the widespread spread of Covid-19 and how to carry out standard operating procedures in isolating when exposed to Covid-19. As well as explaining the various impacts that occur amid the Covid-19 pandemic, both economic, social, and ecological.
\end{abstract}

\begin{abstract}
ABSTRAK
Masyarakat di Desa Batu Balian memiliki karakteristik yang beragam. Ada beberapa RT yang masyarakatnya belum memiliki kesadaran yang lebih untuk mematuhi protokol kesehatan dan juga cenderung tidak mempercayai adanya Virus Covid-19. Maka diperlukan suatu tindakan/metode khusus yang digunakan untuk menyelesaikan persoalan tersebut. Oleh karena itu perlu dilakukan kegiatan Sosialisasi Membangun Desa Tanggap Bencana Covid-19 Di Desa Batu Balian.Penelitian ini menggunakan metode sosialisasi. Sosialisasi di lakukan pada Mahasiswa Program Studi Ilmu Pemerintahan FISIP Universitas Lambung Mangkurat. Sosialisasi ini dilakukan untuk memberikan edukasi kepada masyarakat desa Batu Balian mengenai bahaya, mencegah, dan menanggulangi bencana Covid19, ditengah marakanya penyebaran Covid-19 dan bagaimana cara melakukan standar oprasional prosedur dalam melakukan isolasi saat terpapar Covid-19. Serta memberikan penjelasan tentang berbagai macam dampak yang terjadi ditengah pandemic Covid-19 baik ekonomi, sosial, dan ekologi.
\end{abstract}

\section{Copyright and License:}

Authors retain copyright and grant the journal right of first publication with the work simultaneously licensed under a Creative Commons Attribution 4.0 International License that allows others to share the work with an acknowledgment of the work's authorship and initial publication in this journal. 


\section{PENDAhUluan}

Membangun desa wisata merupakan sebuah kegiatan yang bertujuan untuk mengembangkan potensi wisata di suatu daerah pedesaan. Adapun kegiatan yang dimaksud adalah sebuah usaha peningkatan fasilitas yang memenuhi kebetuhuan wisatawan. Kegiatan ini juga tidak hanya terfokus pada suatu objek wisata saja melainkan secara keseluruhan daerah yang dibina. Sedangkan desa tangguh bencana merupakan kegiatan yang bertujuan untuk memberikan pembinaan terhadap desa mengenai bagaimana cara mengatur kebijakan terhadap ancaman suatu bencana. Cara pelaksanaanya bisa dengan memberikan edukasi yang meliputi kegiatan pencegahan segala potensi bencana, maupun memberikan kegiatan yang bersifat pemulihan atau penyembuhan dari bencana yang sudah terjadi.

Desa Batu Balian merupakan salah satu bagian dari wilayah Kabupaten Banjar, Provinsi Kalimantan Selatan Desa yang berada di Kecamatan Simpang Empat ini menjadi wilayah yang memiliki jumlah penduduk sekaligus wilayah terbesar pada kecamatan tersebut. Berdasarkan data Profil Desa Tahun 2017 terdapat 1.524 Kepala Keluarga (KK) yang tersebar di 8,00 Km² wilayah Desa Batu Balian. Berdasarkan hasil observasi yang kami lakukan, ditemukan jika Desa Batu Balian tidak memiliki wilayah objek wisata maupun potensi wisata. Desa Batu Balian juga tercatat belum pernah mengalami bencana alam, kendati demikian kami bisa menemukan bencana yang mengancam masyarakat Desa Batu Balian yaitu paparan virus COVID-19 yang membahayakan masyarakat. Masyarakat di Desa Batu Balian memiliki karakteristik yang beragam, keberagaman ini ditimbulkan karena kondisi yang berbeda di setiap RT Desa Batu Balian. Ada beberapa RT yang masyarakatnya belum memiliki kesadaran yang kebih untuk mematuhi protokol kesehatan yang ada, masyarakat juga cenderung tidak mempercayai adanya Virus Covid-19 yang bisa membahayakan diri sendiri bahkan orang lain apabila tidak dilakukan penanganan yang sesuai dengan ketentuan yang ada.

Berdasarkan uraian permasalahan di Desa Batu Balian Kecamatan Simpang Empat Kabupaten Banjar maka diperlukan suatu tindakan/metode khusus yang digunakan untuk menyelesaikan persoalan tersebut. Oleh karena itu perlu dilakukan kegiatan Sosialisasi Membangun Desa Tangguh Bencana Covid19 Di Desa Batu Balian 1.

\section{METODE}

Penelitian ini menggunakan metode sosialisasi. Sosialisasi ialah proses interaksi sosial dimana seseorang atau kelompok masyarakat memperoleh pengetahuan, nilai, sikap dan perilaku esensial untuk berpartisipasi secara efektif dalam masyarakat (James. W. Vander Zanden).

Alasan pengambilan metode sosialisasi ini disebabkan oleh beberapa hal, yaitu berdasarkan hasil observasi yang dilakukan, ditemukan bahwa Desa Batu Balian tidak memiliki wilayah objek wisata maupun potensi wisata serta tidak tercatat pernah mengalami suatu bencana alam. Meskipun begitu, ditemukan bahwa Masyarakat Desa Batu Balian masih rentan terpapar virus COVID-19. Selain itu, masyarakat di Desa Batu Balian memiliki karakteristik yang beragam, yang mana hal tersebut disebabkan oleh kondisi masyarakat yang berbeda di setiap RT Desa Batu Balian. Ada beberapa RT yang masih belum memiliki kesadaran untuk mematuhi protokol kesehatan yang ada, dan masyarakat cenderung tidak percaya tentang adanya virus COVID-19 yang sebenarnya dapat membahayakan diri sendiri dan orang lain jika tidak dilakukan penanganan dan pencegahan yang sesuai dengan ketentuan yang berlaku.

Sementara itu, sosialisasi dilakukan setelah berkoordinasi dengan masing-masing ketua RT untuk mengundang masyarakat untuk menghadiri sosialisasi yang dilakukan secara non-formal dan langsung bertatap muka dengan kuota atau jumlah yang terbatas untuk menghindari kerumunan yang bertentangan dengan protokol kesehatan. Sosialisasi dibawakan dengan suasana yang santai, tidak menggunakan perangkat pembantu seperti microphone dan tidak menggunakan bahasa formal untuk membangun kedekatan dengan masyarakat Desa Batu Balian.

\section{HASIL DAN PEMBAHASAN}

Pengabdian yang dilakukan adalah "Sosialisasi Tanggap Bencana Covid-19 di Desa Batu Balian”. Sosialisasi di lakukan pada Mahasiswa Program Studi Ilmu Pemerintahan FISIP Universitas Lambung Mangkurat. Sosialisasi ini dilakukan untuk memberikan edukasi kepada masyarakat desa Batu Balian mengenai bahaya, mencegah, dan menanggulangi bencana Covid-19, ditengah marakanya penyebaran Covid-19 dan bagaimana cara melakukan standar oprasional prosedur dalam melakukan isolasi saat terpapar Covid-19. Serta memberikan penjelasan tentang berbagai macam dampak yang terjadi ditengah pandemic Covid-19 baik ekonomi, sosial, dan ekologi. Tahapan yang dilakukan pada kegiatan pengabdian sebagai berikut: 


\section{Tahapan Persiapan}

Masyarakat yang terlibat dalam meksanakan sosialisasi yaitu seluruh warga Desa Batu Balian RT 1 s/d 5. Sosialisasi berlokasi di Puskesdes (Gambar 1) dan rumah Warga Desa Batu Balian dan menyiapkan sarana prasarana yang dibutukan dalam pengabdian masyarakat seperti buku, pulpen,dan smartphone.

\section{Tahapan Pelaksanaan}

Pada tahap pelaksanaan, langkah pertama yaitu menyusun materi yang simpel dan edukatif untuk memberikan sosialisasi mengenai Covid-19 dan melakukan pencegahan terhadap penyebaran Covid-19 dengan melakukan isolasi mandiri di rumah. Kemudian melakukan diskusi kelompok sederhana bersama para warga (Gambar 2) di 5 RT di Desa Batu Balian mengenai kasus penyebaran Covid-19 di Desa Batu Balian berseta cara pencegahannya.

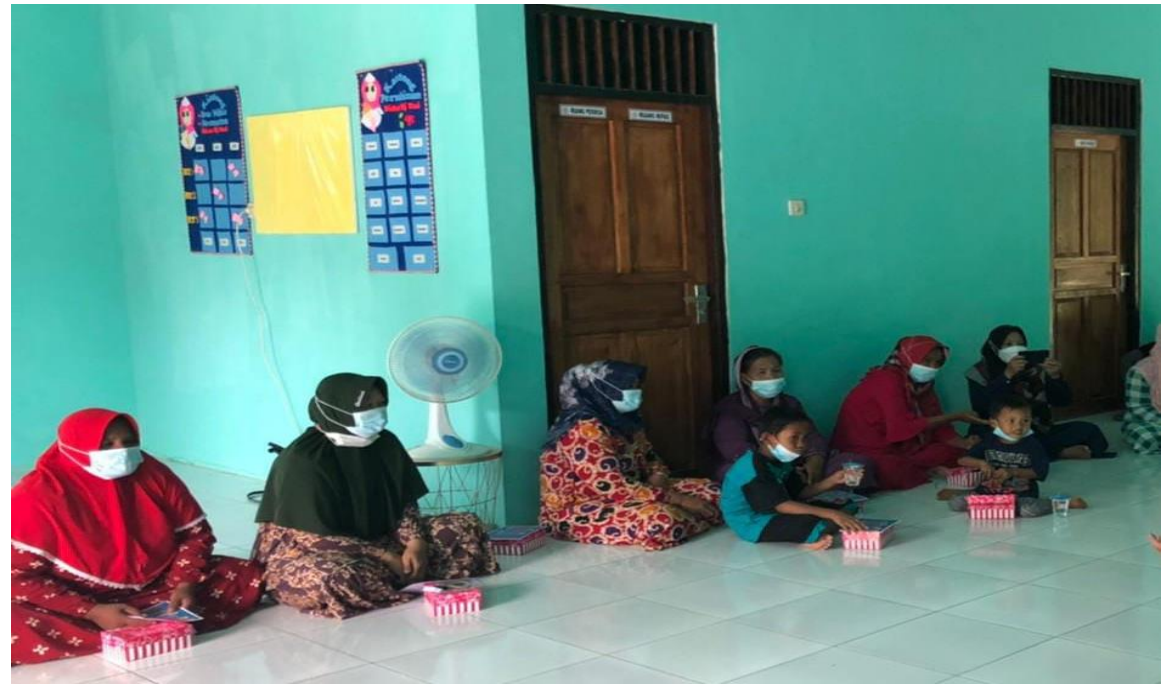

Gambar 1 : Sosialisasi Tanggap Bencana Covid-19 di Puskesdes Desa Batu Balian

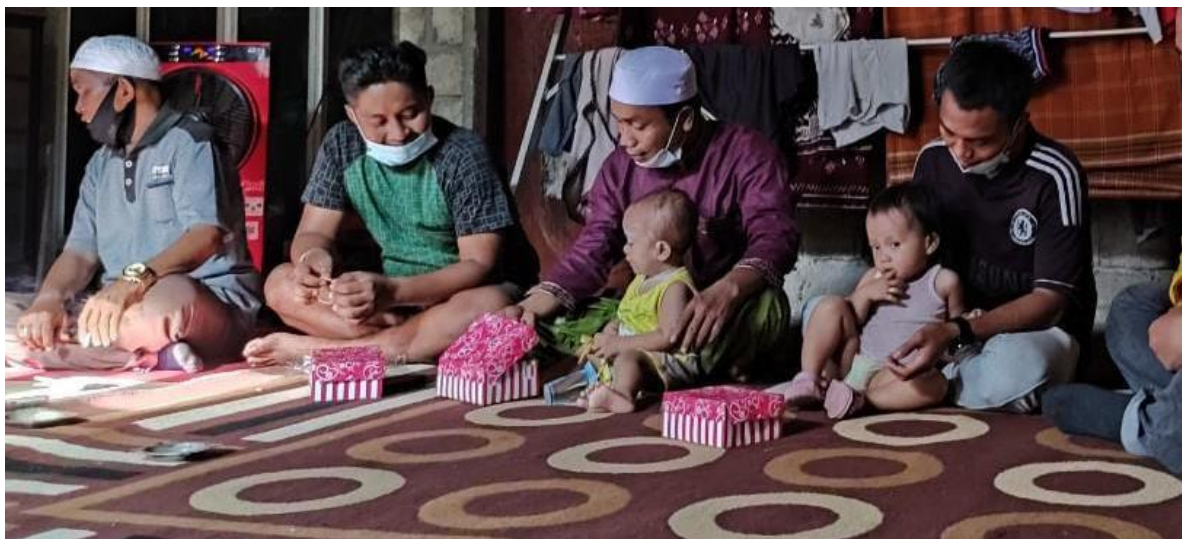

Gambar 2 : Sosialisasi Tanggap Bencana Covid-19 di Rumah Warga Desa Batu Balian

\section{HASIL KEGIATAN} kegitan:

Setelah pelaksanaan kegiatan pengabdian yaitu berupa sosialisasi maka berikut ini ketercapaian

1. Warga Desa Batu Balian memahami pentingnya mengetahui langkah-langkah yang tepat dalam menghindari Covid dan pencegahan serta penanganannya ketika terkena Covid-19.

2. Warga Desa Batu Balian memahami bagaimana cara melakukan standar oprasional prosedur dalam melakukan isolasi mandiri di rumah saat terpapar Covid-19.

3. Pelaksanaan program ini berjalan dengan baik dan lancar sesuai dengan perencanaan di awal. Hasil yang diperoleh juga baik, para perangkat Desa Batu Balian dan masyarakatnya sangat mendukung dan supportif dalam kegiatan ini, melihat antusias masyarakat dalam mengikuti program pengabdian yang kami laksanakan. 


\section{GEOGRAFIS DESA BATU BALIAN}

\section{A. Keadaan Geografis Desa}

Desa Batu Balian merupakan desa dengan wilayah terbesar di Kecamatan Simpang Empat, Kabupaten Banjar. Letak desa yang strategis karena posisi desa yang persis didepan dan berada pada jalur nasional, sehingga akses menuju desa sangat mudah dijangkau. Desa Batu Balian juga memiliki hasil sumber daya alam yang melimpah, baik itu pertambangan, pertanian maupun perkebunan. Selain itu, Desa Batu Balian juga memiliki fasilitas publik yang cukup lengkap jika dibandingkan dengan desa di Kecamatan Simpang Empat lainnya. Fasilitas publik yang tersedia yaitu ; dibidang retail (Alfamart dan Indomaret), Restoran Cepat Saji (Roken Chicken), Olahraga (Lapangan Sepak Bola, Lapangan Bulutangkis, Lapangan Tenis dan Lapangan Voli), Ibadah (Masjid dan Mushola) dan lain-lain.

\section{- Batas Wilayah Desa}

Adapun batas wilayah yang dimiliki Desa Batu Balian dengan wilayah desa lainnya adalah :

\begin{tabular}{|c|l|l|l|}
\hline No. & \multicolumn{1}{|c|}{ Batas } & \multicolumn{1}{|c|}{ Desa/Kelurahan } & \multicolumn{1}{c|}{ Kecamatan } \\
\hline 1. & Sebelah Utara & Sungkai & Simpang Empat \\
\hline 2. & Sebelah Selatan & Simpang Empat & Simpang Empat \\
\hline 3. & Sebelah Timur & Madu Rejo & Sambung Makmur \\
\hline 4. & Sebelah Barat & Keramat Mina & Cintapuri Darussalam \\
\hline
\end{tabular}

Table 2.1 Batas Wilayah Desa Batu Balian

Sumber : Profil Desa Pada Tahun 2017

\section{- Luas Wilayah Menurut Penggunaan}

Secara keseluruhan Desa Batu Balian memiliki luas wilayah sekitar 8,00 $\mathrm{Km}^{2}$, adapun luas wilayah berdasarkan penggunannya adalah :

\begin{tabular}{|c|l|c|}
\hline No. & \multicolumn{1}{|c|}{ Jenis Wilayah } & Luas (Ha) \\
\hline $\mathbf{1 .}$ & Tanah Persawahan & 161 \\
\hline $\mathbf{2 .}$ & Tanah Keringa & 198.89 \\
\hline $\mathbf{3 .}$ & Tanah Basah & 0,8 \\
\hline $\mathbf{4 .}$ & Tanah Perkebunan & 1.396 \\
\hline $\mathbf{5 .}$ & Tanah Fasilitas Umum & 544,42 \\
\hline $\mathbf{6 .}$ & Tanah Hutan & $1.827,06$ \\
\hline
\end{tabular}

Table 2.2 Luas Wilayah Desa Batu Balian Menurut Penggunannya

\section{B. Keadaan Demografis Desa}

Sumber : Profil Desa Pada Tahun 2017

Berdasarkan data Profil Desa Tahun 2017, Desa Batu Balian tercatat memiliki 4.980 jiwa dengan jumlah laki-laki sebanyak 2.471 jiwa dan perempuan 2.509 jiwa. Adapun jumlah Kepala Keluarga (KK) sebanyak 1.524.

\section{Kondisi Pemerintahan Desa}

- $\quad$ Struktur Organisasi Desa

Struktur Kepemimpinan Desa Batu Balian Tidak terlepas dari pada Struktur Administratf Pemerintahan pada level di atasnya, berikut adalah bagan struktur pemerintahan Desa Batu Balian : 


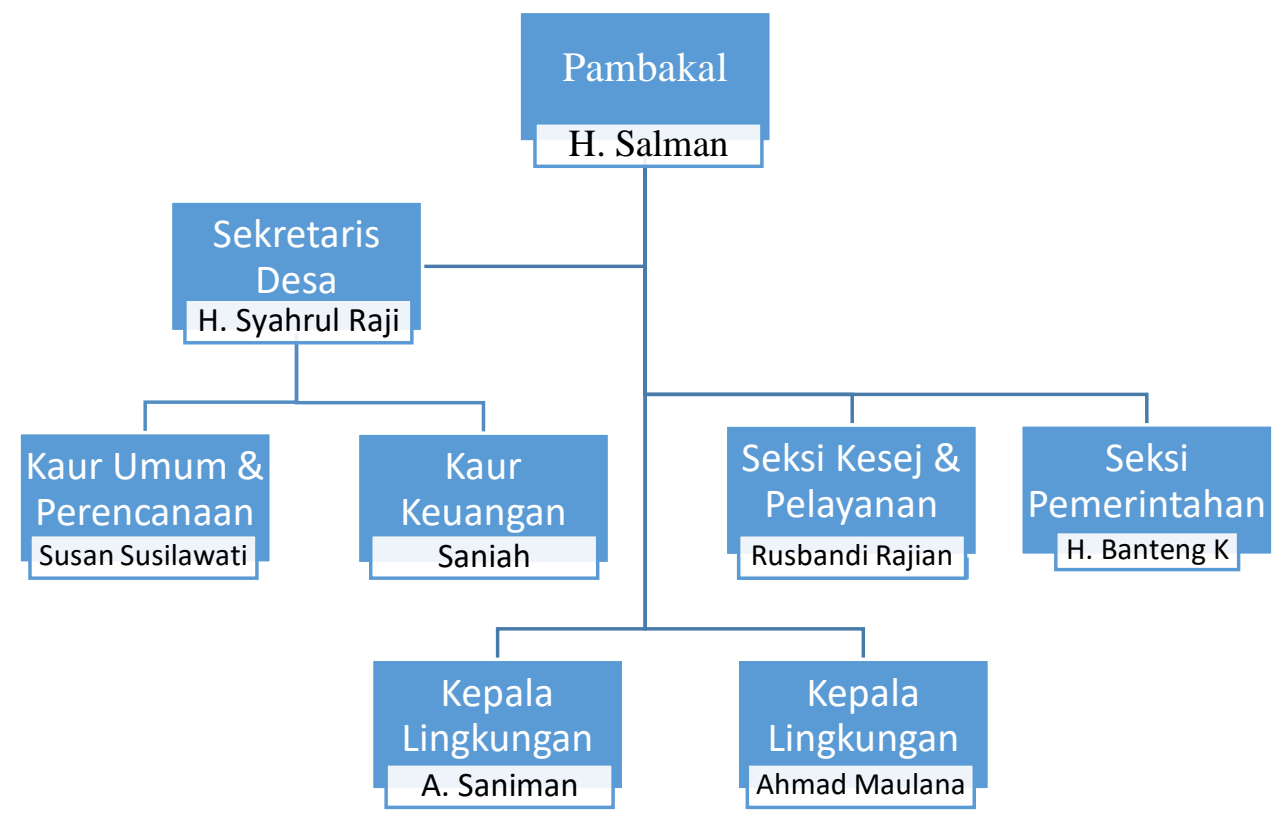

- $\quad$ Kondisi Sosial dan Budaya Masyarakat

Masyarakat Desa Batu Balian memiliki beberapa aktifitas yang masih kental akan budaya yang berhubungan dengan keagamaan, seperti melakukan yasinan, membaca burdah, tadarus AL-Qur'an, dan membaca Maulid Nabi Muhammad SAW. Meningat seluruh penduduk desa memeluk agama Islam. Kehidupan masyarakat juga terdiri atas beragam suku yakni Suku Banjar, Suku Jawa, Suku Madura dan lain-lain. Kendati demikian, mereka hidup rukun dan berdampingan.

Anak-anak Desa Batu Balian meskipun sudah terpapar kehidupan modern seperti gadget, tetapi mereka juga kerap bermain bersama diluar rumah. Mereka gemar bermain sepak bola, kasti, voli, bulu tangkis dan lain-lain secara bermai-ramai. Mengingat Desa Batu Balian terfokus untuk membangun desa yang gemar berolahraga. Kegiatan tersebut juga difasilitasi oleh pemerintah desa dengan menyediakan lapangan untuk setiap cabang olahraga. Desa Batu Balian bahkan memiliki sebuah pelatihan khusus sepak bola untuk pemudanya.

- Kondisi Ekonomi Desa

Kehidupan perekonomian masyarakat desa terbilang cukup beragam, mengingat ada beberapa profesi yang digeluti. Mulai dari pengusaha dibidang pertambangan, perdagangan, pertanian, perkebunan, hingga buruh tambang. Ini dibuktikan dengan banyaknya lahan yang digunakan sebagai tempat berkebun dan bertani seperti sawah, kebun karet, dan kebun sawit.

- Kondisi Sarana dan Prasarana

Berbicara mengenai permasalahan sarana dan prasarana Desa Batu Balian bisa dikatakan sangat lengkap. Mulai dari jalan disekeliling desa yang sudah menggunakan aspal, hingga sarana penunjang seperti retail (Alfamart dan Indomaret), restauran makanan cepat saji, gedung dan lapangan berbagai cabang olahraga, dan penunjang kehidupan masyarakat desa lainnya.

Kendati demikian fasilitas pendidikan di Desa Batu Balian masih cukup kurang, mengingat gedung sekolah formal hanya tersedia sampai tingkat Sekolah Dasar (SD).

- Persebaran Covid-19 di Desa Batu Balian

Berdasarkan hasil observasi yang kami lakukan diketahui jika angka kasus Covid-19 di Desa Batu Balian sangat rendah. Sedangkan angka kematian terkonfirmasi Covid-19 kurang dari lima orang. Namun, keadaan ini juga disebabkan akan ketidakpercayaan masyarakat terhadap virus Covid-19. Sehingga banyak yang tidak memerikasakan diri saat mengalami gejala Covid-19 ke fasilitas kesehatan yang ada. 


\section{KESIMPULAN}

Pelaksanaan Kuliah Kerja Nyata ( KKN ) TEMATIK Lokasi di Desa Batu balian Kecamatan Simpang Empat berjalan dengan baik. Program yang telah dilaksanakan meliputi 2 Bidang yaitu Tanggap Bencana Dan Pariwisata yang sesuai dengan Tema KKN TEMATIK FISIP ULM. Partisipasi dan Dukungan masyarakat yang relatif cukup tinggi, dimana masyarakat turut aktif dalam pelaksanaan program sehingga masyarakat dapat mengambil manfaatnya dengan maksimal.

Walaupun Program KKN TEMATIK FISIP ULM berjalan dengan baik, namun ada beberapa kendala dan hambatan seperti dalam pelaksanaan program, seperti kurangnya waktu yang diberikan pihak panitia KKN dalam melaksanakan KKN ini serta persiapan yang kurang ketika program dilaksanakan. Berbagai Program Kerja dalam KKN ini semoga dapat memberikan banyak bagi mahasiswa KKN dan Warga Desa Batu Balian terutama dalam Tanggap dalam Menghadapi Pandemi Covid-19

\section{UCAPAN TERIMA KASIH}

Ucapan terima kasih disampaikan kepada FISIP Universitas Lambung Mangkurat yang telah mendukung terlaksananya kegiatan ini.

\section{REFERENSI}

Dinas Kesehatan, N. (2020). Pemerintah Serius, Siap dan Mampu Menangani COVID-19 Masyarakat Tetap Tenang \& Waspada. https://corona.ntbprov.go.id/

Yuliana. (2020). Corona virus diseases (Covid-19); Sebuah tinjauan literatur. Wellness and Healthy Magazine.

KKN, 2021. Laporan Kelompok: Kuliah Kerja Nyata (KKN) Lokasi Desa Batu Balian Kabupaten Banjar. 